\title{
Simulasi Arus dan Distribusi Sedimen secara 3 Dimensi di Pantai Selatan Jawa
}

\author{
Muhammad Ghilman Minarrohman, dan Danar Guruh Pratomo \\ Departemen Teknik Geomatika, Fakultas Teknik Sipil dan Perencanaan, Institut Teknologi Sepuluh \\ Nopember \\ e-mail: guruh@geodesy.its.ac.id, ghilman13@mhs.geodesy.its.ac.id
}

\begin{abstract}
Abstrak-Pantai selatan Jawa merupakan daerah pesisir yang berbatasan langsung dengan Samudera Hindia. Batas inilah yang secara langsung mempengaruhi karakteristik oseanografi di daerah pantai Selatan Jawa. Fenomena sedimentasi dari tahun ke tahun juga semakin besar, hal ini dibuktikan dengan berubahnya garis pantai di selatan Jawa, banyak pantai yang mengalami abrasi dan banyak juga yang mengalami akresi. Penelitian ini bertujuan untuk mengetahui dampak dari proses abrasi dan sedimentasi di daerah pantai selatan Jawa berdasarkan pola sebaran arus yang terdapat di daerah penelitian. Model hidrodinamika digunakan untuk melakukan simulasi pola sebaran arus dan sebaran sedimen. Simulasi ini dilakukan pada dua bulan yaitu bulan Maret (mewakili curah hujan tertinggi) dan bulan Oktober (mewakili curah hujan terendah). Dari hasil simulasi di area penelitian, pola arus yang terjadi di wilayah tersebut memiliki nilai kurang dari $6,921 \mathrm{~m} / \mathrm{s}$ pada bulan Maret dan 7,60 m/s pada bulan Oktober. Besar konsentrasi sedimen tertinggi yang terjadi di sepanjang lokasi penelitian yaitu pada bulan Maret sebesar $8972,23 \mathrm{~g} / \mathrm{m3}$ dan pada bulan Oktober sebesar 4247,26 g/m3.
\end{abstract}

Kata Kunci —Pemodelan, Pola Arus, Sedimentasi.

\section{PENDAHULUAN}

$\mathrm{P}$ ANTAI Selatan Jawa merupakan daerah pesisir yang berbatasan langsung dengan laut lepas yaitu Samudera Hindia, batas inilah yang secara langsung membentuk karakteristik dari parameter Oseanografi yang terjadi di daerah pantai Selatan Jawa, selain parameter oseanografi, laut selatan juga membentuk geologi yang unik yang membentuk kondisi oseanografi yang berbeda dibanding dengan laut yang lain. Pantai selatan lebih banyak mengalami abrasi dan memiliki karakteristik perairan yang lebih dalam karena berbatasan dengan Samudera Indonesia yang memiliki arus dan gelombang lebih besar daripada Laut Jawa [1].

Pergerakan sedimen dipengaruhi oleh kecepatan arus dan ukuran butiran sedimen. Semakin besar ukuran butiran sedimen tersebut maka kecepatan arus yang dibutuhkan juga akan semakin besar untuk mengangkut partikel sedimen tersebut [2]. Arus juga merupakan kekuatan yang menentukan arah dan sebaran sedimen. Kekuatan ini juga yang menyebabkan karakteristik sedimen berbeda sehingga pada dasar perairan disusun oleh berbagai kelompok populasi sedimen. Secara umum partikel berukuran kasar akan diendapkan pada lokasi yang tidak jauh dari sumbernya, sebaliknya jika halus akan lebih jauh dari sumbernya [3].
Sedimen adalah material-material yang terbentuk dari perombakkan batuan tua atau dari proses pengikisan batuan yang terbawa air, udara, dan es, atau material yang diendapkan oleh proses yang terjadi secara alami seperti precipitasi kimia atau sekresi oleh organisme, yang kemudian membentuk suatu lapisan di permukaan bumi[2]. Sedimen dipengaruhi oleh kecepatan arus dan ukuran butiran sedimen. Semakin besar ukuran butiran sedimen tersebut maka kecepatan arus yang dibutuhkan juga akan semakin besar untuk mengangkut partikel sedimen tersebut [4]. Arus juga merupakan kekuatan yang menentukan arah dan sebaran sedimen. Kekuatan ini juga yang menyebabkan karakteristik sedimen berbeda sehingga pada dasar perairan disusun oleh berbagai kelompok populasi sedimen.

Di pantai Selatan Jawa fenomena sedimentasi dari tahun ke tahun juga semakin besar, hal ini dibuktikan dengan berubahnya garis pantai di Selatan Jawa, banyak pantai yang mengalami abrasi dan banyak juga yang mengalami akresi. Namun dari pemerintah maupun masyarakat masih belum mengetahui seberapa besar sedimentasi yang terjadi di pantai Selatan Jawa. Perlu ada informasi mengenai sedimentasi yang terjadi di pantai Selatan Jawa dan bagaimana pola arah sebaran sedimennya sehingga pemerintah maupun masyarakat dapat mengetahui daerah mana yang akan mengalami sedimentasi yang besar.

Pada penelitian ini dilakukan simulasi dan analisis pola sebaran arus dan arah distribusi sebaran sedimen di pantai selatan Jawa. Dalam penelitian ini disajikan hasil pemodelan pola arus dan arah distribusi sebaran sedimen yang terjadi di sepanjang pesisir pantai Selatan Jawa dengan program pengolah arus dan sedimen secara 3D.

\section{METODOLOGI PENELITIAN}

\section{A. Lokasi Penelitian dan Data yang digunakan}

Penelitian ini berlokasi di sepanjang kawasan Pantai Selatan Jawa yang terletak pada posisi geografis $9^{\circ} 49^{\prime} 3.71 " \mathrm{~S}$ $114^{\circ} 50^{\prime} 54.46^{\prime \prime} \mathrm{T}$ sampai dengan $7^{\circ} 2^{\prime} 33.22^{\prime \prime} \mathrm{S} \quad$ $104^{\circ} 30^{\prime} 38.63^{\prime \prime} \mathrm{T}$ dengan batas wilayah sebelah utara adalah Pulau Jawa, sebelah timur, barat dan selatan adalah Samudera Hindia. Area tersebut selanjutnya dilakukan pemodelan hidrodinamika menggunakan pendekatan numeric finite volume dengan model barotropik. Data garis pantai yang didapatkan dari Coastal Extraction dan data batimetri yang 
diperoleh dari GEBCO (General Bathymetric Chart of the Ocean) digunakan untuk pembuatan mesh.

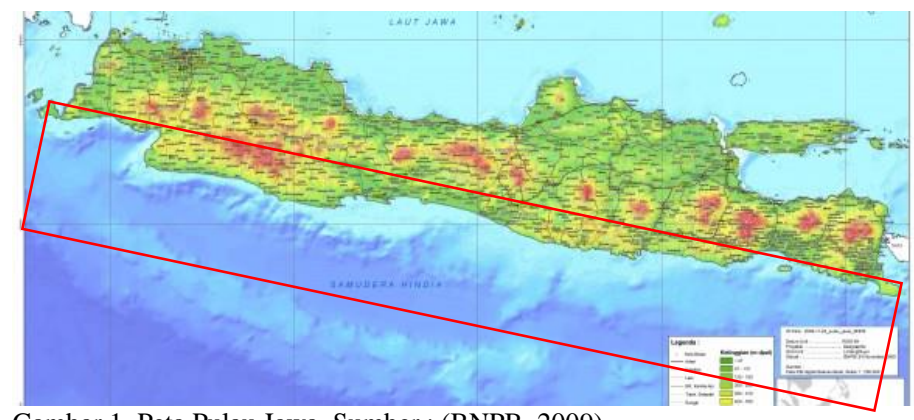

Gambar 1. Peta Pulau Jawa, Sumber : (BNPB, 2009)

Pada area batas dibangkitkan dengan data pasang surut dari 11 stasiun di sepanjang pantai selatan Jawa yang didapatkan dari pengamatan BIG dan 5 stasiun di lepas pantai yang didapatkan dari data prediksi pasang surut BIG. Data angin daerah pantai selatan Jawa yang dikeluarkan oleh BMKG (Badan Meteorologi, Klimatologi dan Geofisika) yang digunakan untuk input data angin pada pemodelan arus. Data nilai grain size diasumsikan nilainya seragam $1,4 \mathrm{~mm}$ yaitu berupa pasir. Untuk validasi model digunakan data arus hasil pengolahan data altimetri.

\section{B. Tahap Pengolahan Data}

Pemodelan diawali dengan memasukkan batas tertutup, yaitu garis pantai seluruh pulau yang termasuk ke dalam domain model. Selanjutnya garis pantai ini di-redistribute untuk mengatur jarak titik-titik pembentuk garis pantai. Batas terbuka model dibuat di perairan terbuka sehingga domain telah menjadi sistem tertutup. Batas terbuka model ini juga perlu di-redistribute.

Setelah batas domain di permukaan terbentuk maka langkah selanjutnya adalah melakukan gridding berupa unstructered mesh. Grid berbentuk segitiga yang ukurannya berbeda-beda. Selanjutnya sepanjang batas terbuka dan sepanjang waktu simulasi di-input data pasang surut per jam.

Pembuatan domain model diakhiri dengan menginput batimetri. Sehingga domain model terbentuk berupa ruang perairan tiga dimensi. Batimetri diinterpolasi terhadap grid yang sudah dibuat. Data angin per hari digunakan di seluruh permukaan domain model dan sepanjang waktu simulasi.

Hasil simulasi berupa arus tiga dimensi dan elevasi tiap jam selama waktu simulasi di setiap lapisan domain model. Arus terdiri dari tiga komponen yaitu $\mathrm{u}$ dan $\mathrm{v}$ mewakili arus horisontal dan w mewakili arus vertikal.

Hasil simulasi model arus yang digunakan sebelumnya dilakukan validasi kualitas data arus antara data arus hasil pengolahan altimetri dan hasil pemodelan. Jika kualitas data memenuhi dapat disimpulkan bahwa algoritma pengolahan data berjalan baik dan data arus tersebut dapat digunakan untuk pemodelan arus dan pemodelan transpor sedimen.

Verifikasi data didapat dengan menghitung nilai RMSE (Root Mean Square Error) yang menunjukkan tingkat kesalahan suatu data dalam persentase nilai. Perhitungan untuk mencari nilai tersebut adalah :
$R M S E=\sqrt{\frac{\sum_{i=1}^{n}\left(x_{a, i}-x_{b i j}\right)^{2}}{n}}=\sqrt{\frac{\sum_{i=1}^{n}\left(x_{o b g, i}-x_{m o d e l, i}\right)^{2}}{n}}=$

dengan $\mathrm{n}, \mathrm{X}_{\mathrm{obs}}, \mathrm{X}_{\text {model }}$ berturut-turut adalah jumlah data, data lapangan dan data hasil model. Model dikatan diterima apabila nilai RMSE kurang dari 1.

Setelah model arus diakatakan valid maka selanjtnya dilakukan simulasi model transpor sedimen. Dalam simulasi model transpor sedimen digunakan parameter dari karakteristik sedimen yaitu grain size sediment. Untuk durasi pemodelan dimasukkan timestep yang sama dengan pemodelan arus yaitu 19 hari. Output pada simulasi model transpor sedimen yaitu area series.

\section{HASIL DAN ANALISIS}

\section{A. Hasil Pemodelan Batimetri}

Pada proses pemodelan sebaran sedimen terlebih dahulu dilakukan messing area dan plotting kedalaman dari wilayah pantai selatan Jawa dengan menggunakan modul Mesh Generator.

Untuk boundary condition seperti yang ditunjukkan pada Gambar 3 ditentukan berdasarkan garis pantai dan koordinat stasiun pengamatan pasang surut BIG pada bagian atas yang ditunjukan dengan simbol titik hitam, sedangkan batas bagian bawah menggunakan batas buatan serta ditentukan berdasarkan lokasi koordinat pasang surut prediksi yang didapatkan dari BIG yang berada di lepas pantai.

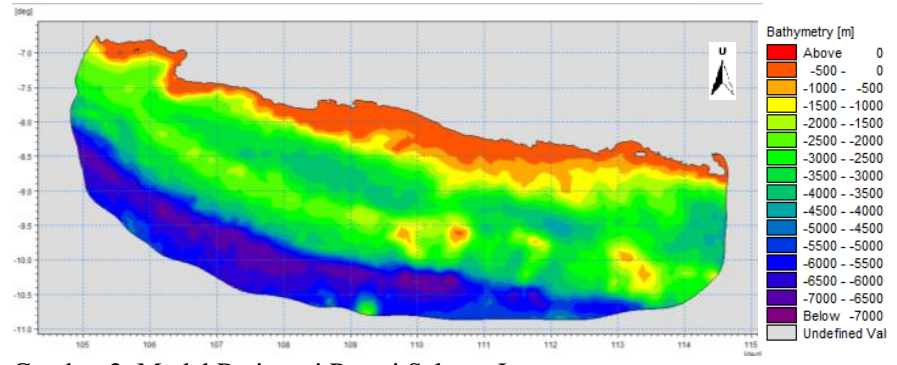

Gambar 2. Model Batimetri Pantai Selatan Jawa

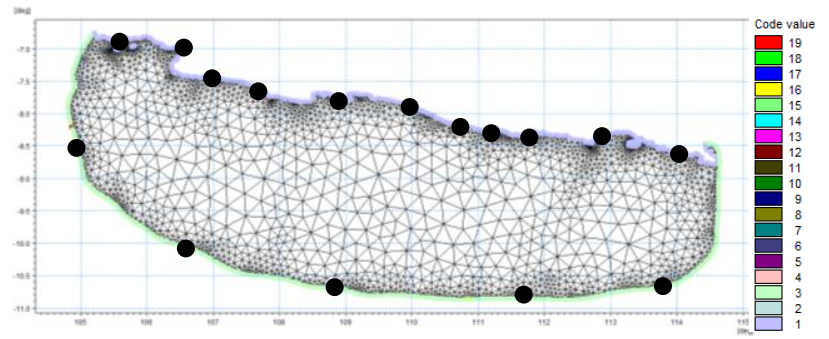

Gambar 3. Pembuatan Boundary Condition Dan Lokasi Stasiun Pasang Surut

\section{B. Pemodelan Hidrodinamika}

Proses ini menggunakan parameter pasang surut untuk pembuatan model hidrodinamika dan dibuat dalam 2 model yaitu model bulan Maret yang dimulai tanggal 26 Februari 2016 pukul 00:00:00 sampai 16 Maret pukul 00:00:00 dan bulan Oktober yang dimulai tanggal 27 September 2016 pukul 00:00:00 sampai 16 Oktober pukul 00:00:00. Model tersebut akan menggunakan durasi waktu selama 19 hari, dimana waktu warming up selama 4 hari dan waktu simulasi selama 15 hari. 
Pemodelan ini memiliki timestep sebanyak 456 dengan interval waktu per 3600 detik.

\section{Simulasi Data Pasang Surut}

Pasang surut yang dihasilkan dari pemodelan menunjukan bahwa secara grafik sesuai dengan data pasang surut di 15 lokasi stasiun pasang surut yang didapat dari BIG, dan data tersebut dapat digunakan untuk proses pemodelan. Referensi data pasang surut dihitung dari MSL. Berikut adalah perbandingan grafik antara pasang surut pemodelan dan pasang surut BIG di 15 stasiun Pasang Surut :

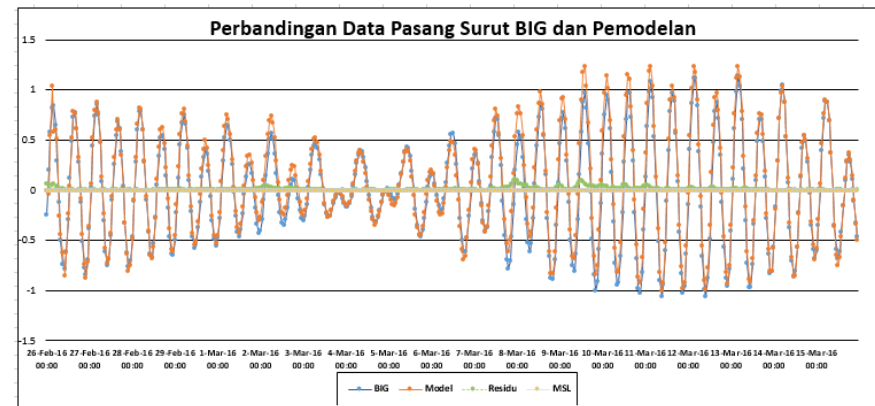

Gambar 4. Grafik Pasang Surut Perbandingan Antara Hasil Perbandingan Dengan BIG Stasiun Sadeng Bulan Maret 2016.

Dari data pasang surut BIG dan pasang surut hasil model, dapat dilakukan validasi hasil pemodelan. Validasi dilakukan dengan menghitung Root Mean Square Error (RMS Error). Berikut adalah nilai RMSE dari masing-masing stasiun:

Tabel 1.

Nilai RMSE validasi arus

\begin{tabular}{|c|c|c|c|}
\hline \multirow{2}{*}{ No } & \multirow{2}{*}{ Stasiun } & \multicolumn{2}{|c|}{ RMSE } \\
\hline & & Maret & Oktober \\
\hline 1 & Binuangeun & 0.29954 & 0.234123 \\
\hline 2 & Pelabuhan Ratu & 0.1688 & 0.13586 \\
\hline 3 & Ciagra & 0.339305 & 0.276237 \\
\hline 4 & Pameungpeuk & 0.19792 & 0.124707 \\
\hline 5 & Cilacap & 0.349799 & 0.45667 \\
\hline 6 & Purworejo & 0.245271 & 0.270215 \\
\hline 7 & Sadeng & 0.103519 & 0.112213 \\
\hline 8 & Pacitan & 0.196668 & 0.115403 \\
\hline 9 & Prigi & 0.321498 & 0.315751 \\
\hline 10 & Sendang Biru & 0.484761 & 0.35621 \\
\hline 11 & Banyuwangi & 0.304879 & 0.295413 \\
\hline 12 & Stasiun 1 & 0.262217 & 0.259259 \\
\hline 13 & Stasiun 2 & 0.324893 & 0.232294 \\
\hline 14 & Stasiun 3 & 0.117191 & 0.126285 \\
\hline 15 & Stasiun 4 & 0.160527 & 0.15129 \\
\hline 16 & Stasiun 5 & 0.350156 & 0.28541 \\
\hline
\end{tabular}

Dari perhitungan didapatkan bahwa nilai $R M S E<1$, dan mendekati 0. Sehingga, dapat dikatakan bahwa hasil pemodelan yang dijalankan adalah baik dan valid.
D. Hasil Simulasi Pola Sebaran Arus dari Model Hidrodinamika 3 Dimensi

Hasil dari pemodelan disajikan dalam keadaan pasang tertinggi dan surut terendah pada bulan Maret dan Oktober yang ditampilkan pada Gambar 5 - 8. Pada keadaan pasang tertinggi bulan Maret (Gambar 5) terlihat bahwa arus bergerak menuju daratan dan pada keadaan surut terendah bulan Maret (Gambar 6) terlihat bahwa arus semakin besar bergerak menjauhi arah daratan dan elevasi muka air menurun.

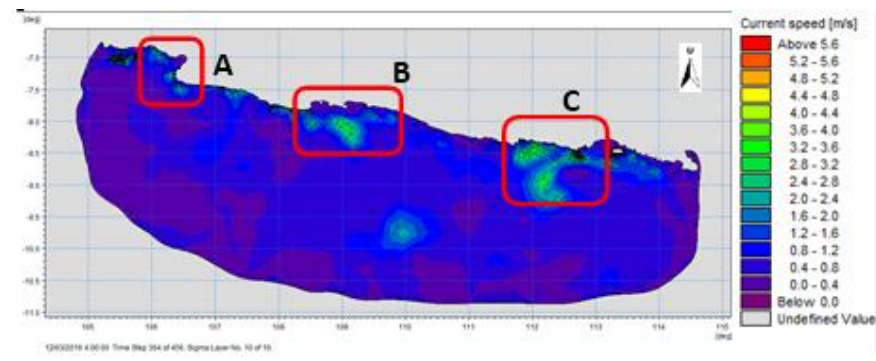

Gambar 5. Kondisi Pasang Tertinggi Bulan Maret 2016

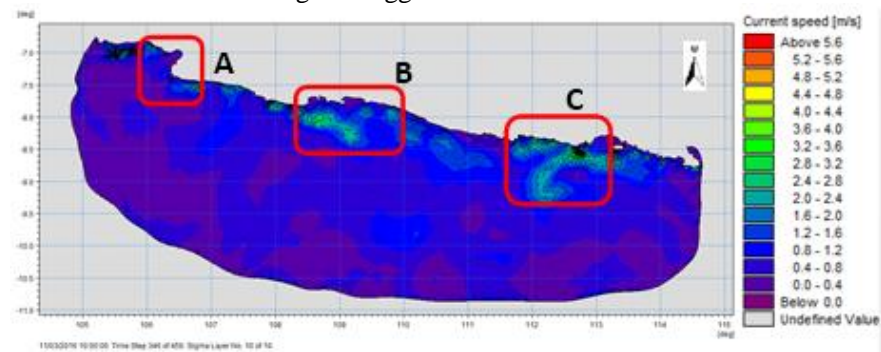

Gambar 6. Kondisi Surut Terendah Bulan Maret 2016

Pada keadaan pasang tertinggi bulan Oktober (Gambar 7) terlihat bahwa arus bergerak menuju daratan dan pada keadaan surut terendah bulan Oktober (Gambar 8) terlihat bahwa arus semakin besar bergerak menjauhi daratan dan elevasi muka air menurun.

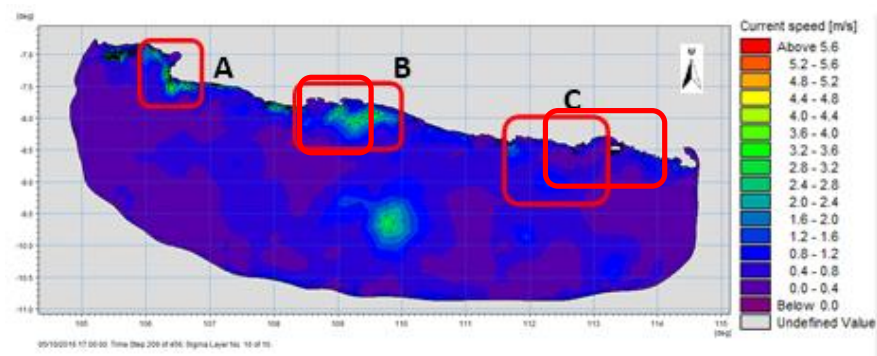

Gambar 7. Kondisi Pasang Tertinggi Bulan Oktober 2016

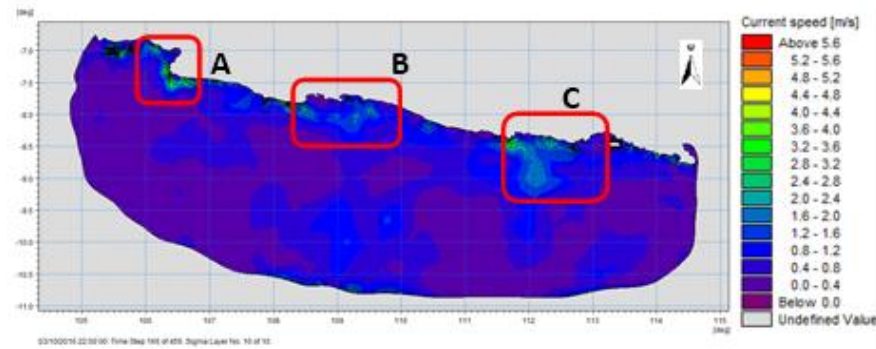

Gambar 8. Kondisi Surut Terendah Bulan Oktober 2016

Dari pemodelan terlihat besar kecepatan arus maksimum dari hasil simulasi adalah 6,92 $\mathrm{m} / \mathrm{s}$ pada bulan Maret dan 7,60 $\mathrm{m} / \mathrm{s}$ pada bulan Oktober. 


\section{E. Pemodelan Transpor Sedimen}

Simulasi transpor sedimen dilakukan untuk mengetahui pola penyebaran sedimen yang terjadi. Hasil dari simulasi ini adalah pola sebaran sedimen untuk kondisi pasang tertinggi, dan surut terendah, besar suspended sedimen concentration dan bed level change (perubahan dasar perairan). Parameter yang digunakan pada pembuatan simulasi model transpor sedimen sama dengan parameter yang digunakan pada pemodelan hidrodinamika. Hanya saja pada pembuatan simulasi pola sebaran sedimen dimasukkan nilai grain size sedimen.

\section{F. Perbandingan Arus}

Sebelum melanjutkan kedalam simulasi transpor sedimen, hasil kecepatan arus pemodelan dibandingkan dengan data arus pengamatan. Untuk mengidentifikasi nilai arus model dilakukan dengan membandingkan data arus model dengan arus geostropik yang telah diolah dari satelit Altimetri dengan melakukan perhitungan nilai RMS Error. Perhitungan ini menggunakan 8 titik arus model dan 8 titik arus geostropik.

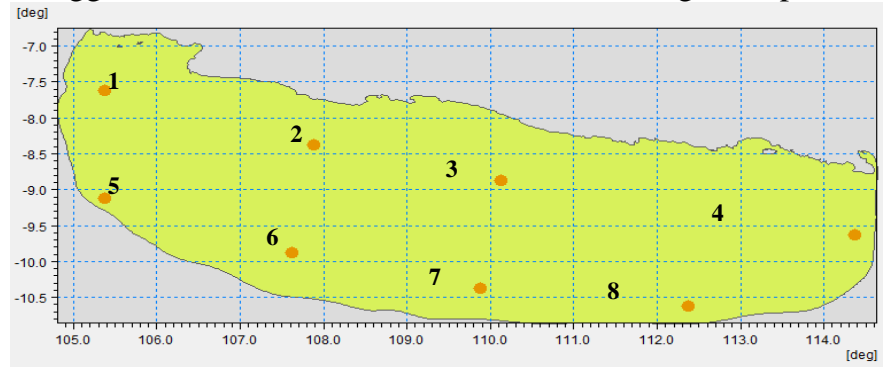

Gambar 9. Lokasi titik uji validasi arus.

Tabel 2 Hasil RMSE Arus Bulan Maret dan oktober

\begin{tabular}{ccccc}
\hline \hline \multirow{2}{*}{ No } & LONG (dec. & LAT (dec. & \multicolumn{2}{c}{ RMSE } \\
\cline { 4 - 5 } & Degree) & Degree) & Maret & Oktober \\
\hline 1 & 105.375 & -7.625 & 0.037 & 0.310 \\
2 & 107.875 & -8.375 & 0.695 & 0.997 \\
3 & 110.125 & -8.875 & 0.900 & 0.125 \\
4 & 114.375 & -9.625 & 0.754 & 0.270 \\
5 & 105.375 & -9.125 & 0.465 & 0.064 \\
6 & 107.625 & -9.875 & 0.359 & 0.457 \\
7 & 109.875 & -10.375 & 0.116 & 0.731 \\
8 & 112.375 & -10.625 & 0.091 & 0.856 \\
\hline \hline
\end{tabular}

Dari hasil nilai RMS Error yang telah didapatkan pada kedua data tersebut dapat dikatakan pemodelan yang dilakukan valid karena nilai RMSE < 1 . Pada bulan Maret nilai RMSE terkecil adalah 0.037 dan yang terbesar 0.900. Sedangkan nilai RMSE pada bulan Oktober yang terkecil dan terbesar adalah 0.064 dan 0.997 .

\section{G. Hasil Pemodelan Transpor Sedimen}

Untuk model transpor sedimen terlihat pada Gambar 10 dan 11 menjelaskan model pada saat pasang tertinggi dan surut terendah pada bulan Maret dan Oktober 2016. Dari hasil simulasi terlihat sebaran sedimen dipengaruhi oleh pola arus yang dibangkitkan oleh pasang surut namun tidak terlalu berpengaruh besar.

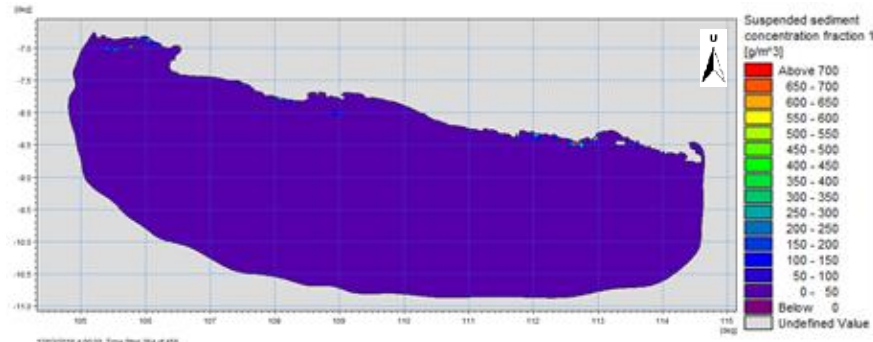

Gambar 10. Kondisi Pasang Tertinggi Bulan Maret 2016

Dari gambar diatas dapat dilihat bahwa karena luasnya daerah yang dimodelkan sehingga untuk melihat pola sebaran sedimen di pantai selatan Jawa maka harus di zoom daerah yang terlihat perubahan pola sebaran sedimennya signifikan.

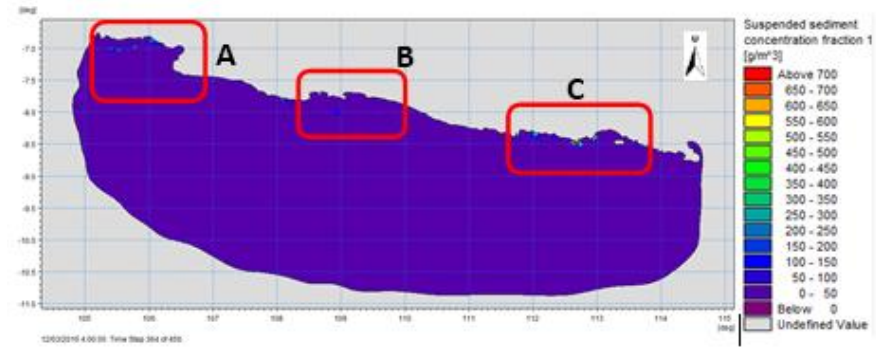

Gambar 12. Penentuan Lokasi Pola Sebaran Sedimen

Lokasi A adalah lokasi di wilayah Binuangeun, Banten. Lokasi B adalah lokasi di wilayah Cilacap, dan lokasi C adalah lokasi di wilayah Malang.

Pada kondisi pasang tertinggi bulan Maret dimana arus bergerak ke arah pesisir, sedimen terangkut menuju pesisir dan konsentrasi sedimen yang masuk terbawa arus pada saat pasang tertinggi pada lokasi B lebih besar daripada konsentrasi sedimen yang keluar.

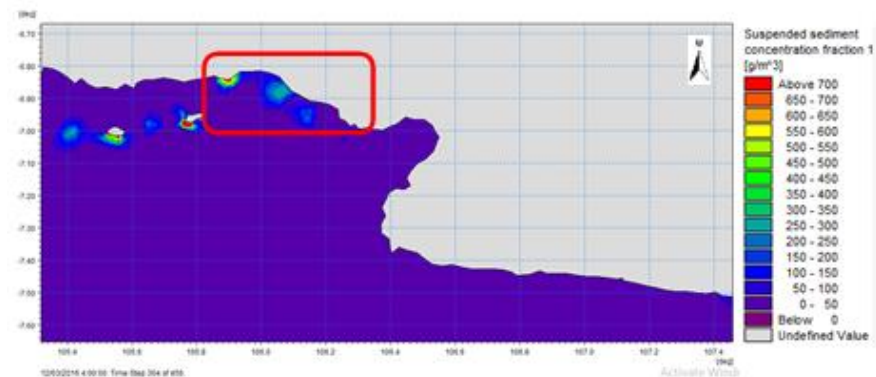

Gambar 13. Pola Sebaran Sedimen Di Lokasi A Pantai Selatan Jawa Saat Kondisi Pasang Tertinggi Bulan Maret 2016

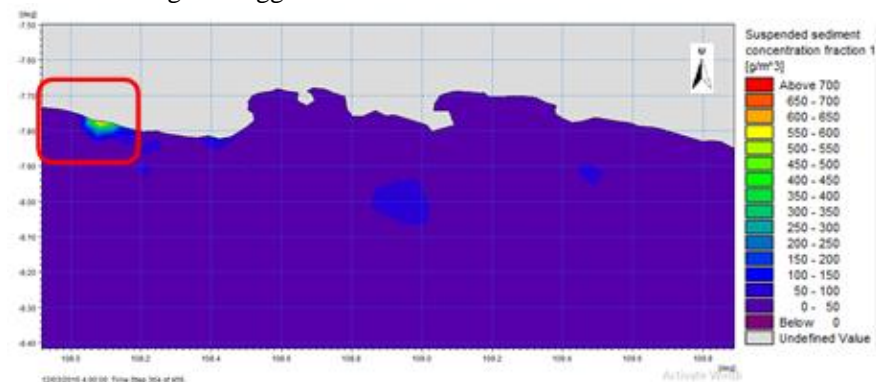

Gambar 14. Pola Sebaran Sedimen Di Lokasi B Pantai Selatan Jawa Saat Kondisi Pasang Tertinggi Bulan Maret 2016 


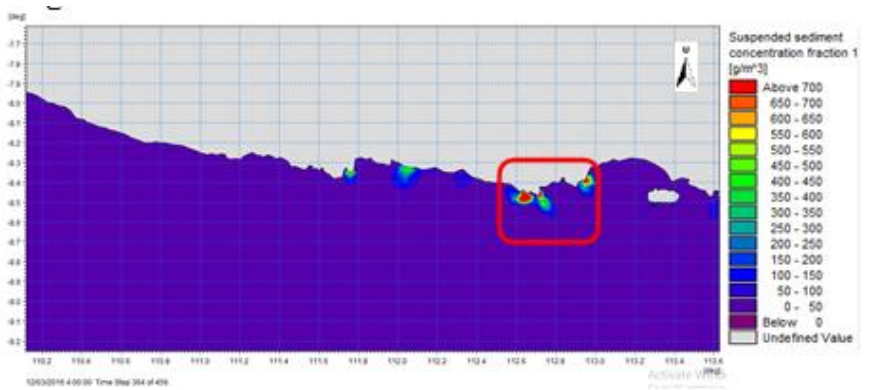

Gambar 15. Pola Sebaran Sedimen Di Lokasi C Pantai Selatan Jawa Saat Kondisi Pasang Tertinggi Bulan Maret 2016

Pada kondisi surut terendah dimana arus bergerak menjauhi daratan, konsentrasi sedimen yang keluar menjauhi pantai pada lokasi A dan C lebih besar daripada konsentrasi sedimen yang masuk.

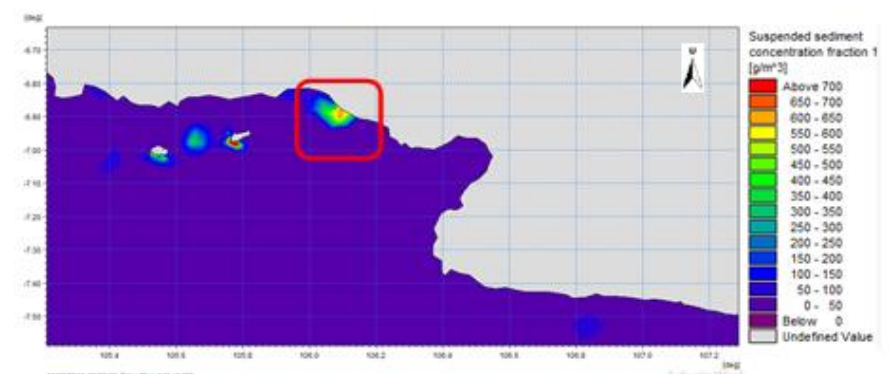

Gambar 16. Pola Sebaran Sedimen Di Lokasi A Pantai Selatan Jawa Saat Kondisi Surut Terendah Bulan Maret 2016

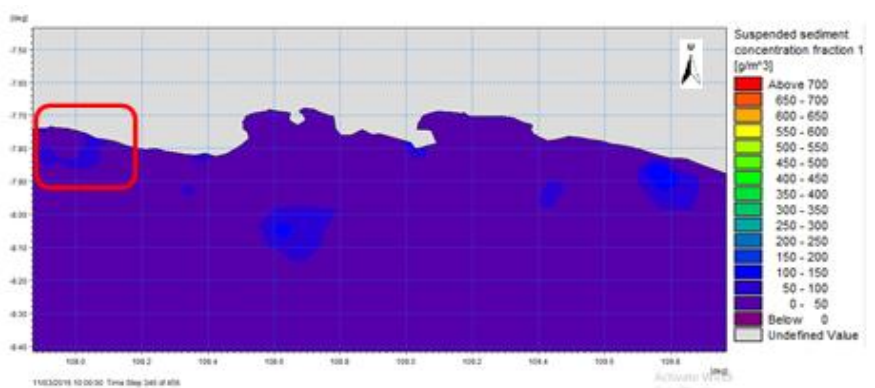

Gambar 17 Pola Sebaran Sedimen Di Lokasi B Pantai Selatan Jawa Saat Kondisi Surut Terendah Bulan Maret 2016

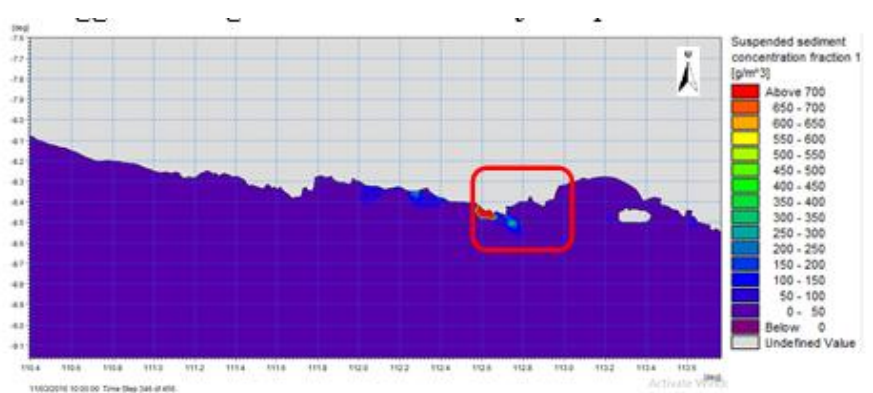

Gambar 18. Pola Sebaran Sedimen Di Lokasi C Pantai Selatan Jawa Saat Kondisi Surut Terendah Bulan Maret 2016

Pada kondisi pasang tertinggi bulan Oktober dimana arus bergerak ke arah pesisir, sedimen terangkut menuju pesisir dan konsentrasi sedimen yang masuk terbawa arus pada saat pasang tertinggi pada lokasi A lebih besar daripada konsentrasi sedimen yang keluar.

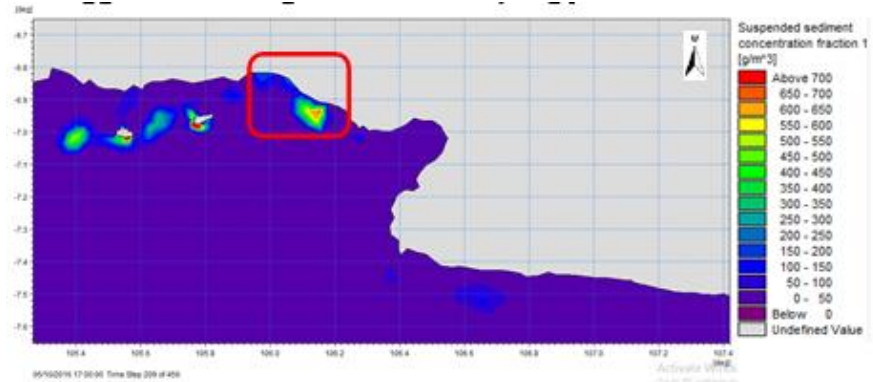

Gambar 19. Pola Sebaran Sedimen Di Lokasi A Pantai Selatan Jawa Saat Kondisi Pasang Tertinggi Bulan Oktober 2016

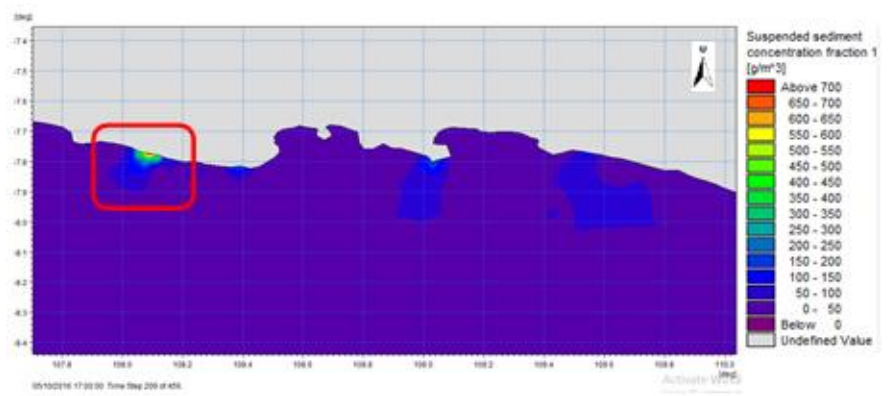

Gambar 20. Pola Sebaran Sedimen Di Lokasi B Pantai Selatan Jawa Saat Kondisi Pasang Tertinggi Bulan Oktober 2016

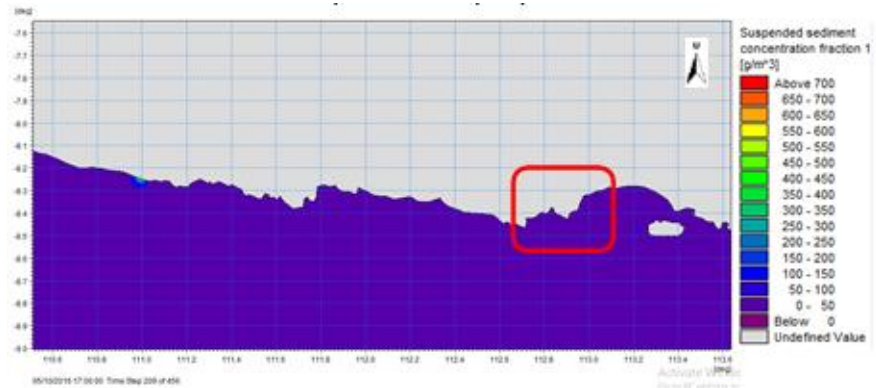

Gambar 21. Pola Sebaran Sedimen Di Lokasi C Pantai Selatan Jawa Saat Kondisi Pasang Tertinggi Bulan Oktober 2016

Pada kondisi menuju surut dan surut terendah dimana arus bergerak menjauhi daratan, konsentrasi sedimen yang keluar menjauhi pantai pada lokasi B dan C lebih besar daripada konsentrasi sedimen yang masuk.

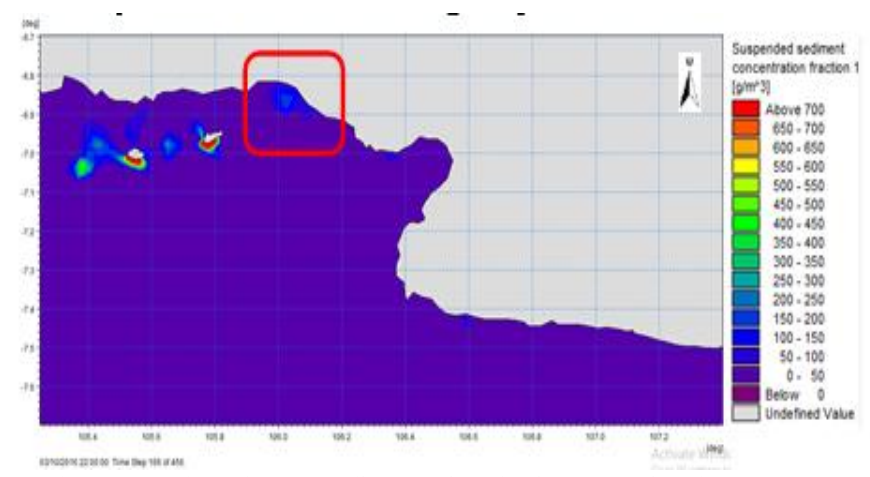

Gambar 22. Pola Sebaran Sedimen Di Lokasi A Pantai Selatan Jawa Saat Kondisi Surut Terendah Bulan Oktober 2016 


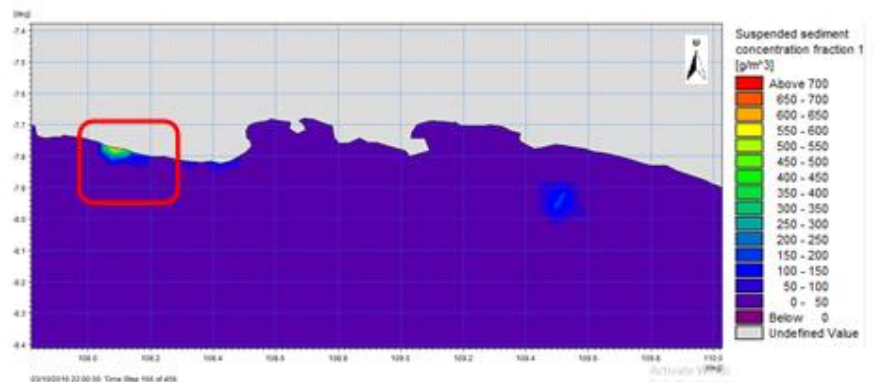

Gambar 23. Pola Sebaran Sedimen Di Lokasi B Pantai Selatan Jawa Saat Kondisi Surut Terendah Bulan Oktober 2016

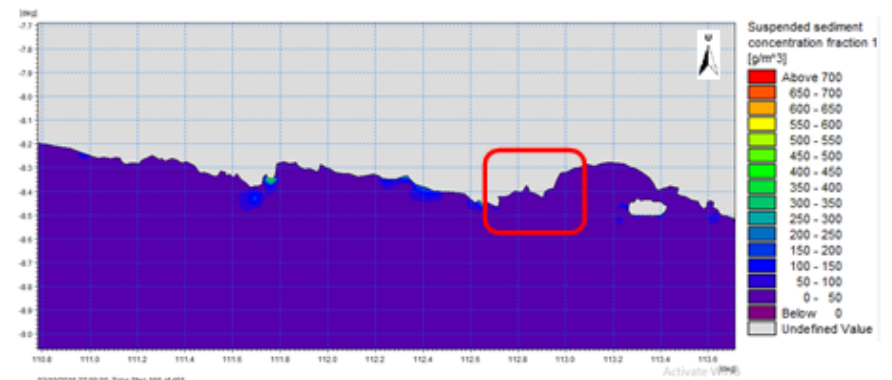

Gambar 24. Pola Sebaran Sedimen Di Lokasi C Pantai Selatan Jawa Saat Kondisi Surut Terendah Bulan Oktober 2016

Dari pemodelan terlihat konsentrasi sedimen maksimum pada bulan Maret sebesar 8972,23 g/m3 dan konsentrasi sedimen pada bulan Oktober sebesar 4247,26 g/m3.

\section{KESIMPULAN}

Berdasarkan hasil penelitian ini, dapat disimpulkan bahwa:

1. Model pola arus di pantai selatan Jawa pada saat kondisi pasang tertinggi bulan Maret dan bulan Oktober arus bergerak ke arah pesisir dan pada kondisi surut terendah bulan Maret dan bulan Oktober arus bergerak ke arah yang berlawanan. Besar kecepatan arus maksimum dari hasil simulasi adalah $6,92 \mathrm{~m} / \mathrm{s}$ pada bulan Maret dan 7,6 m/s pada bulan Oktober. Hal ini menunjukan bahwa kondisi perairan pantai selatan Jawa memiliki arus yang cukup besar dan berubah sesuai pasang surut.
2. Model pola sebaran sedimen di pantai selatan Jawa dapat dilihat pada bulan Maret dan bulan Oktober. Konsentrasi sedimen pada bulan Maret memiliki nilai maksimal sebesar $6484,19 \mathrm{~g} / \mathrm{m}^{3}$ (lokasi A), 774,534 $\mathrm{g} / \mathrm{m}^{3}$ (lokasi B), dan $8972,23 \mathrm{~g} / \mathrm{m}^{3}$ (lokasi C). Sedangkan besar konsentrasi sedimen pada bulan Oktober memiliki nilai maksimal sebesar 4247,26 g/m $\mathrm{m}^{3}$ (lokasi A), 864,887 g/m³ (lokasi B), dan $854,038 \mathrm{~g} / \mathrm{m}^{3}$ (lokasi C). Konsentrasi sedimen pada lokasi A mengalami penurunan dan cenderung bergerak kearah timur, pada lokasi B mengalami peningkatan, dan pada lokasi $\mathrm{C}$ mengalami penurunan yang signifikan.

3. Jenis sedimen pada pantai selatan Jawa yang berupa pasir dengan nilai Grain Size 0.2, sesuai dengan diagram Hjulstrom akan ter transport jika kecepatan arusnya 2-20 $\mathrm{cm} / \mathrm{s}$ atau $0.02-0.2 \mathrm{~m} / \mathrm{s}$. Dan berdasarkan kecepatan arus hasil pemodelan dengan kecepatan maksimum 7,6 m/s, maka sedimen di pantai selatan Jawa akan ter transport mengkuti arah arus.

Beberapa hal yang dapat disarankan pada akhir penelitian ini adalah:

1. Perlu mengambil sampel sedimen agar mengetahui nilai grain size sedimen yang akurat.

2. Sebaiknya menggunakan pemodelan hidrodinamika baroklinik dengan memasukkan data suhu, salinitas, dan parameter lain.

\section{DAFTAR PUSTAKA}

G. Y. Pradipta, "Perairan Jawa Barat," 2012. [Online]. Available: url: \%0Ahttp://anucara-gdyatha.blogspot.co.id/2012/04/perairanjawa-barat.html\%3E\%0A.

[2] A. . Daulay, "Karakteristik Sedimen Di Perairan Sungai Carang Kota Rebah Kota Tanjungpinang Provinsi Kepulauan Riau," Univ. Marit. Raja Ali Haji, 2014.

[3] R. . Munandar, "Karakteristik Sedimen Di Periran Desa Tanjung Momong Kecamatan Siantan Kabupaten Kepulauan Anambas," Univ. Marit. Raja Ali Haji, 2013.

[4] H. S. dan E. S. M, Pengantar Oseanografi. Jakarta: Universitas Indonesia Press, 2006. 